Acta vet. scand. 1984, 25, 29-35.

From the State Veterinary Serum Laboratory, Copenhagen, Denmark.

\title{
SEROLOGICAL COMPARISON OF TYPE STRAINS OF PORCINE, BOVINE, AND OVINE MYCOPLASMAS WITH ATYPICAL COLONY MORPHOLOGY
}

By

N. F. Friis and P. Thode Jensen

FRIIS, N. F. and P. T. JENSEN: Serological comparison of type strains of porcine, bovine, and ovine mycoplasmas with atypical colony morphology. Acta vet. scand. 1984, 25, 29-35. - The type strains of Mycoplasma hyopneumoniae, M. flocculare, M. dispar, and M. ovipneumoniae, all characterized by nipple-less colonies on solid media, were compared serologically. By indirect hemagglutination and by complement fixation tests they were found to constitute a related group. By crossed immunoelectrophoresis a sharing of common antigens was demonstrated, whereas no cross reactivity was noted by the metabolism inhibition test.

The type strains of Mycoplasma hyorhinis and Mycoplasma bovirhinis were included in the study for comparison. Although some cross reaction was noted, they appeared just moderately related to the nipple-less group as well as to each other.

serology; porcine mycoplasmas; bovinemycoplasmas; ovine mycoplasmas.

Among the large number of mycoplasmas known to-day, 4 species are unique so far as colony formation on solid medium is concerned, in that they do not show the fried-egg morphology otherwise characteristic of mycoplasmas. The species referred to are: Mycoplasma hyopneumoniae and Mycoplasma flocculare from swine, Mycoplasma dispar from cattle, and Mycoplasma ovipneumoniae from sheep. Other features they have in common are the ability to degrade glucose and a special affinity for the respiratory-tract epithelium. Moreover, they are more or less pathogenic.

The said species are distinct if examined by the recognized serological methods recommended by the International Committee 
on Systematic Bacteriology, Subcommittee on the Taxonomy of Mollicutes (1979), for the separation of mycoplasmas at species level. These methods are: the disc growth inhibition test, the metabolism inhibition test, and the immunofluorescence test on colonies.

It is well known that by more sophisticated serological techniques some degree of interrelationship is often revealed among a greater number of different mycoplasma species. Indeed, by immunodiffusion and by counter-immunoelectrophoresis a relationship has been demonstrated between 3 of the 4 species concerned (Ball \& Todd 1978). In the present work the 4 species have been examined for cross reaction by serological methods which are generally capable of revealing interspecies antigenic relations. Mycoplasma hyorhinis and Mycoplasma bovirhinis were included for comparison.

\section{MATERIAL AND METHODS}

The serological comparison was performed by the indirect hemagglutination test (IHA), the complement fixation test (CF) and two-dimensional immunoelectrophoresis (IE). The metabolism inhibition test (MI) was included for comparison. The antigens for the tests were made from cultures grown in ordinary mycoplasma medium. The antisera, however, were produced in rabbits by inoculation of mycoplasmas grown in a medium based on rabbit broth in order to minimize medium-induced antibody reactions.

\section{Strains of Mycoplasma}

The respective type strains of the following species were used: Mycoplasma hyopneumoniae, "J", NCTC 10110 (M. hyop.); Mycoplasma flocculare, Ms42, NCTC 10143 (M. floc.); Mycoplasma hyorhinis, BTS-7, NCTC 10130 (M. hyor.); Mycoplasma dispar, 462/2, NCTC 10125 (M. dispar); Mycoplasma bovirhinis, PG43, NCTC 10118 (M. bovir.); Mycoplasma ovipneumoniae, Y-98, NCTC 10151 (M. ovip.).

\section{Antigen}

Antigens for the serological tests were produced by cultivation of the mycoplasmas in a medium evolved for growth of Mycoplasma hyopneumoniae (Friis 1975). The cultures (except for 
use in MI) were harvested by centrifugation and washed 3 times in PBS. For IHA and CF the final pellets were resuspended in distilled water to approx. 1/100 of the original volume of medium and thereafter frozen-and-thawed 10 times, and stored at $-25^{\circ} \mathrm{C}$ until use. For IE the pellets, after suspension in $0.008 \mathrm{~mol} / 1 \mathrm{triz}$ ma base, $0.02 \mathrm{~mol} / 1$ glycin and $0.003 \mathrm{~mol} / 1$ sodium azide with $5 \%$ triton X-100 (Serva, Heidelberg) $\mathrm{pH} \mathrm{8.6,} \mathrm{were} \mathrm{sonicated} \mathrm{on}$ ice for $3 \times 45 \mathrm{~s}$ at 1 -min intervals at maximal amplitude on an MSE ultrasonic disintegrator. After centrifugation the supernatants were used as antigen.

\section{Antisera}

The antisera were produced in rabbits using mycoplasma antigen obtained from cultures in rabbit broth (Friis 1977) and prepared as described above for IHA and CF tests. After the process of freeze-thawing PBS was added to 1/15 of the original broth volume. On day zero rabbits were inoculated with a mixture of equal volumes of Freund's incomplete adjuvant and antigen i.m. in both prescapular regions ( $1 \mathrm{ml}$ on each side) and s.c. in the foot pad of the third phalanx of both hind legs $(0.1 \mathrm{ml}$ in each pad). On day 30 the inoculations in the prescapular regions were repeated. Un-adjuvanted antigen, $1 \mathrm{ml}$, was given i.v. on days 0 , $15,30,38,40$, and 42 . Hereafter the rabbits were inoculated i.v. once a week and bled twice a week for 2 months. The sera were pooled and tested for potency by the disc growth inhibition test.

\section{Serological methods}

The MI test was performed as a macrotest using the technique suggested in the recommendations of FAO/WHO (VPH/MIC) 75.6). The IHA test was performed according to the guidelines worked out by Mandrup et al. (1975). The CF test was performed as a direct test in microtiter plates. Veronal-buffered diluent, $\mathrm{pH}$ 7.4, containing $1 \%$ normal rabbit serum, was used. Two $100 \%$ hemolytic units of complement were used. The antigen-antibodycomplement mixture was kept overnight at $+4^{\circ} \mathrm{C}$ and the hemolytic system added next morning. The IE test was performed essentially as described by Axelsen et al. (1973). Electrophoresis was carried out in a $1.0 \%$ agarose gel (W/V) ("Indubiose" A 37, L'industrie Biologique Francaise S.A.) with $0.024 \mathrm{~mol} / \mathrm{l}$ barbital, $0.073 \mathrm{~mol} / 1$ trizma base, $0.6 \mathrm{mmol} / \mathrm{l}$ Ca-lactate, $0.006 \mathrm{~mol} / \mathrm{l}$ 
sodium azide, pH 8.6. The same buffer was used in the electrophoresis vessels. Crossed immunoelectrophoresis with and without intermediate gel was performed in a $0.15 \mathrm{~cm}$ thick gel on $10 \times$ $10 \mathrm{~cm}$ glass plates. While the first dimension was run for $90 \mathrm{~min}$ at $5 \mathrm{~V}$ per $\mathrm{cm}$ at $15^{\circ} \mathrm{C}$, the second dimension was run overnight at $2 \mathrm{~V}$ per $\mathrm{cm}$ at $20^{\circ} \mathrm{C}$. The washed and dried plates were stained with Coomassie Brilliant Blue R.

\section{IHA test}

\section{RESULTS}

M. hyop., M. floc., M. dispar, and M. ovip. were found to crossreact considerably (Table 1 ) in that heterologous titers were often equal to, or just a few steps lower, than the homologous titers. M. dispar and M. ovip. antisera also cross-reacted to a high degree with M. hyor. and M. bovir. antigens. Between M. hyor. and $M$. bovir. cross reaction was minimal.

Table 1. Reciprocals of homologous and heterologous indirect hemagglutination titers of antisera for type strains of some mycoplasma species.

\begin{tabular}{lrrrrrr}
\hline & \multicolumn{7}{c}{ Antiserum } \\
\cline { 2 - 7 } Antigen & M. hyop. & M. floc. & M. dispar & M. ovip. & M. hyor. & M. bovir. \\
\hline M. hyop. & 5000 & 1280 & 2500 & 2500 & 320 & $<10$ \\
M. floc. & 5000 & 20000 & 5000 & 2500 & 640 & 10 \\
M. dispar & 5000 & 2500 & 20000 & 1280 & 640 & 40 \\
M. ovip. & 2500 & 1280 & 5000 & 20000 & 1280 & 20 \\
M. hyor. & 640 & 160 & 1280 & 2500 & 10000 & 40 \\
M. bovir. & $<10$ & $<10$ & 5000 & 2500 & 40 & 10000 \\
\hline
\end{tabular}

\section{CF test}

M. hyop., M. floc., M. dispar, and M. ovip. were found to crossreact considerably, not only with each other, but also with $\mathbf{M}$. hyor. (Table 2). M. bovir., however, appeared more distinct, except for its reaction with $M$. ovip. antiserum.

\section{IE test}

By two-dimensional immunoelectrophoresis, M.hyop., M.floc., M. dispar, and M. ovip. were found to cross-react considerably. M. bovir. antigen gave a comparatively large number of lines against M. ovip. antiserum. M. hyor., and its antiserum as well, reacted 
T a b l e 2. Reciprocals of homologous and heterologous complement fixation titers of antisera for type strains of some mycoplasma species.

\begin{tabular}{lrrrrrr}
\hline & \multicolumn{7}{c}{ Antiserum } \\
\cline { 2 - 7 } Antigen & M. hyop. & M. floc. & M. dispar & M. ovip. & M. hyor. & M. bovir. \\
\hline M. hyop. & 160 & 40 & 20 & 80 & 20 & $<10$ \\
M. floc. & 80 & 320 & 40 & 320 & 40 & $<10$ \\
M. dispar & 80 & 80 & 320 & 320 & 20 & $<10$ \\
M. ovip. & 80 & 80 & 40 & 640 & 40 & $<10$ \\
M. hyor. & 40 & 20 & 20 & 160 & 160 & 10 \\
M. bovir. & 20 & 10 & 10 & 160 & 20 & 640 \\
\hline
\end{tabular}

with a few lines in most of the experiments (Table 3). No precipitation lines were observed with mycoplasma culture medium as antigen (control).

T a b l e 3. Number of precipitation arcs obtained by crossed immunoelectrophoresis of type strains of some mycoplasma species against homologous and heterologous antisera.

\begin{tabular}{lcccccc}
\hline & \multicolumn{7}{c}{ Antiserum } \\
\cline { 2 - 7 } Antigen & M. hyop. & M. floc. & M. dispar & M. ovip. & M. hyor. & M. bovir. \\
\hline M. hyop. & 10 & 4 & 6 & 9 & 3 & 0 \\
M. floc. & 4 & 8 & 3 & 4 & 2 & 0 \\
M. dispar & 5 & 3 & 12 & 11 & 2 & 0 \\
M. ovip. & 6 & 3 & 7 & 14 & 2 & 0 \\
M. hyor. & 1 & 2 & 2 & 2 & 14 & 1 \\
M. bovir. & 0 & 0 & 1 & 4 & 0 & 7 \\
\hline
\end{tabular}

MI test

All strains were significantly inhibited by their homologous antiserum, and no cross reactions were noted except for an insignificant inhibition of M. floc. by M. hyop. antiserum (Table 4).

T a ble 4. Reciprocals of homologous and heterologous metabolism inhibition titers of antisera for type strains of some mycoplasma species.

\begin{tabular}{lrrcccc}
\hline & \multicolumn{7}{c}{ Antiserum } \\
\cline { 2 - 7 } Antigen & M. hyop. & M. floc. & M. dispar & M. ovip. & M. hyor. & M. bovir. \\
\hline M. hyop. & $\mathbf{1 6 0}$ & $<10$ & $<10$ & $<10$ & $<10$ & $<10$ \\
M. floc. & $\mathbf{1 0}$ & $\mathbf{6 4 0}$ & $<\mathbf{1 0}$ & $<10$ & $<\mathbf{1 0}$ & $<10$ \\
M. dispar & $<\mathbf{1 0}$ & $<10$ & $\mathbf{3 2 0}$ & $<10$ & $<10$ & $<10$ \\
M. ovip. & $<10$ & $<10$ & $<10$ & $\mathbf{6 4 0}$ & $<10$ & $<10$ \\
M. hyor. & $<\mathbf{1 0}$ & $<\mathbf{1 0}$ & $<10$ & $<10$ & $\mathbf{1 2 8 0}$ & $<10$ \\
M. bovir. & $<\mathbf{1 0}$ & $<\mathbf{1 0}$ & $<10$ & $<10$ & $<10$ & $\mathbf{1 2 8 0}$ \\
\hline
\end{tabular}




\section{DISCUSSION}

The experiments have shown that all 6 type strains are serologically distinct if examined by the MI test, while by IHA and CF tests high degrees of cross reaction may be noted. By IE many antigens were found to be common to the different species.

The 4 species: M. hyop., M. floc., M. dispar, and M. ovip., are distinct from all other mycoplasmas by the characteristic feature that their colonies on solid medium lack the central nipple otherwise typical of mycoplasmas. By IE these 4 species appeared to form a closely related group, in that the number of cross-reacting precipitates was remarkly large, alhough in all cases less than in the homologous systems. Since the number of cross-reacting precipitates obtained with M. hyor. and M. bovir. was much smaller, especially for M. hyor., it appears that these 2 species are but distantly related to the nipple-less group and to each other. These results confirm the results obtained by Ball \& Todd (1978) in immunodiffusion experiments with the same species, exclusive of M. floc. Similarities in antigenic structure between M. hyop. and M. floc. have been demonstrated earlier by Friis (1977) by the growth precipitation test, and by Rose et al. (1979) by polyacrylamide gel electrophoresis.

The results obtained by the IHA and CF tests add to the evidence of a close antigenic relationship existing between the 4 species of the nipple-less group. Further, M. hyor. and M. bovir. appeared to be rather distinct from that group and from each other, although minor cross reactions did occur. As discussed by Freundt (1974) such minor interspecies reactions are commonly noted in IHA and CF tests.

\section{REFERENCES}

Axelsen, N. H., J. Krøll \& B. Weeke (Eds.): A manual of quantitative immunoelectrophoresis: Methods and applications. Scand. J. Immunol., Vol. 2, Suppl. 1: 1973.

Ball, H. J. \& D. Todd: Comparison of antigens of pneumonia-associated mycoplasma species by gel diffusion. Infect. Immun. 1978, 21, $954-958$.

Freundt, E. A.: Practical aspects of serological identification. Inserm 1974, 33, 161-168.

Friis, N. F.: Some recommendations concerning primary isolation of Mycoplasma suipneumoniae and Mycoplasma flocculare. A survey. Nord. Vet.-Med. 1975, 27, 337-339.

Friis, N.F.: Mycoplasma suipneumoniae and Mycoplasma flocculare in the growth precipitation test. Acta vet. scand. 1977, 18, 168-175. 
Mandrup, M., N. F. Friis, A. Meyling \& J. H. Meding: Studies on the possible occurrence of mycoplasmas in boar semen. Nord. Vet.Med. 1975, 27, 557-561.

Rose, D. L., J. G. Tully \& R. G. Wittler: Taxonomy of some swine mycoplasmas: Mycoplasma suipneumoniae Goodwin et al. 1965, a later, objective synonym of Mycoplasma hyopneumoniae Maré and Switzer 1965, and the status of Mycoplasma flocculare Meyling and Friis 1972. Int. J. syst. Bacteriol. 1979, 29, 83-91.

Subcommittee on the Taxonomy of Mollicutes: Proposal of minimal standards for descriptions of new species of the class Mollicutes. Int. J. syst. Bacteriol. 1979, 29, 172-180.

\section{SAMMENDRAG}

Serologisk sammenligning af typestammerne for porcine, bovine og ovine mykoplasmer med atypisk kolonimorfologi.

4 arter af Mycoplasma, nemlig M. hyopneumoniae og M. flocculare fra svin, M. dispar fra kvæg og M. ovipneumoniae fra får er særegne ved ikke at besidde den for mykoplasmer ellers så karakteristiske spejlægsmorfologi af kolonier på agarplade. Typestammerne for disse 4 arter blev sammenlignet ved forskellige serologiske metoder, og de fandtes at udgøre en antigenmæssigt beslægtet gruppe $i$ den indirekte hæmagglutinationstest og ved komplementbindingspr $\varnothing v e n$. Forekomst af fælles antigener påvistes ved krydset immunelektroforese, men ved væksthæmningstest $\mathbf{i}$ bouillon fandtes ingen krydsreaktion.

Typestammerne for Mycoplasma hyorhinis fra svin og Mycoplasma bovirhinis fra kvæg blev medtaget $i$ arbejdet for sammenligning. Relativt svage krydsreaktioner kunne påvises mellem disse 2 stammer indbyrdes, og mellem dem og den ovenfor omtalte gruppe.

(Received December 30, 1983).

Reprints may be requested from: N. F. Friis, the State Veterinary Serum Laboratory, Bülowsvej 27, DK-1870 Copenhagen V, Denmark. 